\title{
A practical framework to engage students in college teaching
}

Xue Bai, Virginia State University, xbai@vsu.edu

Ade Ola, Virginia State University, aola@vsu.edu

Serena Reese, Virginia State University, sreese@vsu.edu

Ephrem Eyob, Virginia State University,eeyob@vsu.edu

\begin{abstract}
Student engagement has increasingly been positioned as a defining characteristic of high-quality teaching and learning in higher education. The level of student engagement in the learning and instructional process is the vehicle through which classroom instruction influences learning outcomes. The factors impacting engagement and how students are engaged in the learning process have been well-researched. However, there is lack of study on the implementation of various engagement strategies in real-world instructional settings, including face-to-face and online instructional environments. This study is intended to provide a practical framework which can be easily transformed into actual instructional settings through three driving forces to engage students in the learning process; hence the improvement of learning outcomes can be achieved through the implementable activities suggested in the framework.
\end{abstract}

Keywords: engagement activities, learning process, learning outcomes

\section{Introduction}

Student engagement and interest during instruction are important conditions for active learning. Engagement, which has an important relationship with learning motivation, influences students' levels of persistence to overcome challenges and can be measured by the amount of effort that a student puts into setting learning goals, planning and self-monitoring (Fredricks \& McColskey, 2012; Gunuc, 2014). However, college students can easily become discouraged at attending lectures and tutorials across both online and face-to-face settings; lack of student engagement and absence from face-to-face lectures and tutorials, in turn, can lead to poor academic performance (Esposto \& Weaver, 2011; Romer, 2020; Stanca, 2006). One of the underlying assumptions in research on learning is that the use of education technology positively influences student engagement, a vital characteristic of high-quality teaching and learning in higher education, and the outcome of learning (Kahn, Everington, Kelm, Reid \& Watkins, 2017). The use of educational technologies such as multimedia have strong pedagogical advantages in stimulating greater student engagement (Kahn et al., 2017). The global coronavirus disease 2019 (COVID-19) pandemic has hastened the adoption of technology-enhanced learning methods for online or synchronous remote delivery. In instructional practice, the delivery mode notwithstanding, it is common to observe students' lack of interest or motivation in the classroom. This particular behavior is not only hard to correct, but it can be detrimental to the learning dynamics. In recognizing lower retention rates, especially due to the impact of COVID-19, higher education institutions have taken actions to identify problems and explore strategies to engage students in their online studies, ensuring that students will successfully complete a college degree. 


\section{Literature review}

Education services are often intangible and difficult to measure because the outcome is reflected in the transformation of individuals' knowledge, life skills, characteristics, and behavior (Tsinidou, Gerogiannis $\&$ Fitsilis, 2010). Therefore, there is no commonly accepted definition of quality that applies specifically to the higher education sector (Michael, 1998). However, there are many factors affecting the quality of education. Among those factors, student engagement is the learning process that has been identified as one of the most important factors (Al-Zahrani, 2015; Zepke, Leach \& Butler, 2010; Kuh, Cruce, Shoup \& Kinzie, 2008). Student engagement has increasingly been positioned as a defining characteristic of highquality teaching and learning in higher education. Findings from the research concluded that the more actively engaged students were with faculty, other students, and in the subject matter they study, the more likely they learn, stick with their studies, and attain their academic goals.

Issues relating to student retention and student engagement remain high on the agendas for higher education institutions worldwide (Busse, 2013; Zepke et al., 2010). To better understand the impact of student engagement in the learning process, Zepke et al., (2010) completed a comprehensive review of the international engagement literature. According to Zepke and Leach (2010), the way in which students engage with their studies and what the stakeholders, including students, administrators, and faculty can do to improve this engagement has been a well-researched area since the 1990's. Previous research by Zepke et al., (2010) identified a number of lenses through which one can investigate engagement. Their research resulted in the development of a conceptual organizer with two distinct features. The first identifies the key lenses employed within the engagement literature and the second suggests indicators of outcomes that might be achieved by using each lens. The conceptual organizer (Zepke et al., 2010) provides a synthesis of the literature. The factors in the conceptual organizer include student motivation, teacher-student interactions, learners interacting with each other, the role of institutional policies, sociopolitical factors and the role of non-institutional influences such as family, friends, health and employment.

The relationship between student motivation and engagement has also been well-studied. Students who have high motivation make an effort to be engaged in class. Thus, knowing students' motivation levels is important for active engagement during instruction. In psychology, Self-Determination Theory (SDT) is an important concept that refers to each person's ability to make choices and manage their own life (Deci \& Ryan, 2002). The theory suggests that people are able to become self-determined when their needs for competence, connection, and autonomy are fulfilled. The concept of self-determination has been applied to a wide variety of areas including education, work, parenting, exercise, and health. Students' motivation in a learning environment is affected by many other factors, including relationship with faculty and peer students, how the contents are delivered, institutional and non-institutional support, and many other social factors (Zepke et al. 2010; Groves, Sellars, Smith, \& Barber, 2015; Deci \& Ryan, 2002).

There is a strong pattern in the literature (Zepke et al., 2010) which suggests that student-teacher interactions are a crucial factor in encouraging student engagement (Groves et al., 2015; Zepke et al., 2010; Zepke, Butler, \& Leach, 2012; Kuh et al., 2008; Radovan, 2019). Umbach and Wawrzynski (2005) argued that teacher-student interactions are perhaps the most important factor in encouraging student learning and seemed to challenge teachers and institutions to place a higher value on this particular role. To encourage student engagement, faculty need to be enthusiastic and well prepared (Bryson \& Hand, 2007; Krause \& Coates, 2008; Russell \& Slater, 2011). Peer relationships also appear to be important in encouraging student engagement (Krause \& Coates, 2008; Moran \& Gonyea, 2003; Umbach \& Wawrzynski, 2005). The relationship among learners can be developed and improved by giving them group work to foster active and collaborative learning (Zepke \& Leach, 2010). The level of engagement is also influenced by the 


\section{Issues in Information Systems}

Volume 22, Issue 4, pp. 83-92, 2021

learning environment provided by institution and non-instructional factors including family, friends, health and employment (Zepke et al., 2010).

In addition to the aforementioned dimensions, perceived enthusiastic teaching style, clear objectives and appropriate assessment methods significantly enhanced students' cognitive engagement in the learning process (Lizzio, Wilson \& Simons, 2002; McCormick, Kinzie \& Gonyea, 2013). A review of the literature on student engagement has also revealed that student motivation to engage in the learning process can be enhanced by feelings of competence (Llorens, Schaufeli, Bakker, \& Salanova, 2007; Russell \& Slater, 2011; Yorke \& Knight, 2004; Zepke \& Leach, 2010; DiMenichi \& Tricomi, 2015).

Thus, there are many factors that affect student engagement. The way in which students engage with their studies and what the stakeholders including students, administrators, and faculty can do to improve this engagement has been well-researched. However, there is lack of implementable action plans that can be easily transformed into real instructional settings. Therefore, the purpose of this study is to provide a practical framework that can be implemented in real instructional and learning process with minimum effort.

\section{Developing a framework for student engagement}

Many factors impact students' engagement in the learning process. However, in developing a practical framework, this research paper focuses on the dimensions that are manageable from the perspective of faculty. Thus, the focus is on course content and how content is delivered in different instructional settings. The literature (Llorens et al., 2007; Russell \& Slater, 2011; Yorke \& Knight, 2004; Zepke \& Leach, 2010; DiMenichi \& Tricomi, 2015) revealed the two most important factors to engage students in the learning process are interaction between faculty and students and among peer students and how content is delivered. Thus, the framework being proposed focuses on content design and activities associated with the content delivery process.

A well-designed course content should allow teaching and learning to be organized in an engaging manner. Nowadays, student's learning experience is almost entirely mediated through some form of technology. According to previous research (Bai, Ola, Eyob, Reese, Akkaladevi \& Downing, 2019), the majority of students used online resources instead of assigned reading materials because those resources were directly tied to assessments, concise to read and contained rich multimedia contents (pictures, videos, etc.). For example, YouTube has been listed is the top one learning tool since 2019 (source: https://www.toptools4learning.com) . Other tools on the top 5 list include zoom, Google Search, PowerPoint, Microsoft Teams. Therefore, the design of course content is critical to engaging students in the learning process. Having an effective course design requires at least the following:

- Establish a routine for students.

- Integrate activities that invite and excite student participation.

- Provide ways for students to track their progress.

The fundamental task of professors is to get students engaged in learning activities that are likely to result in achieving the desired learning outcomes. Activities should include those in which students collaborate in group assignments, solve problems together or individually, or get involved in experiential learning projects involving dialogue and shared research. Presentations, debates, "pop" quizzes or oral presentation, and competitions are all teaching strategies that emphasize active student effort over passive instructor-led presentations. Activities should be designed in such a way that 1. they are in alignment with learning objectives and directly related to the contents discussed; 2 . students are cognitively motivated to participate; 


\section{Issues in Information Systems}

Volume 22, Issue 4, pp. 83-92, 2021

3. they boost students' learning experiences (students are satisfied by participating, learn something new or apply what they have learned, etc.).

To identify the most practical activities to engage students in the learning process, several faculty members from different schools at a regional university in the South-Central region held five brainstorming sessions to discuss how to engage students in the learning process in their face-to-face, synchronous remote instruction, and asynchronous online classes. The engagement activities used in classes and others identified from literature are summarized below:

Quizzes: As an assessment tool, quiz is a good motivation tool for engaging students in the learning process. Various research efforts (Yorke \& Knight, 2004; Zepke \& Leach, 2010; DiMenichi \& Tricomi, 2015; Holmes, 2018) have concluded that students are more focused when they take quizzes or any kind of assessment.

Live group discussion (synchronous discussion): In our observation, students showed more engagement when they participated in a live (synchronous) discussion, compared to asynchronous discussions; students were inspired by instant feedback or comments from instructors and peer students.

Instructional games: Instructional games are gaining popularity in the classroom as they effectively engage students and provide immediate feedback. In real instructional settings, the use of these tools is often limited due to lack of time and insufficient experience. Tournament tool, similar to kahoot, is a game-based technology solution to create engagement and active learning. The real-time feedback provides opportunities for professors in various disciplines to tailor their instruction based on student understanding on quizzes while the surveys allow for anonymous classroom participation, which further engages all students. The following two activities (tournament and poll) are part of the instructional games.

Tournament in class: Giving quizzes through tournaments. Competition can increase motivation, improve productivity and performance, and provide accountability and validation (Llorens et al., 2007; Russell \& Slater, 2011; Yorke \& Knight, 2004; Zepke \& Leach, 2010; DiMenichi \& Tricomi, 2015).

Poll: Polling allows students to choose from a variety of activity types, the results of which are presented visually in real time. Polls may be open-ended Q \& As, multiple choice, or word clouds. Each activity type encourages audience participation and allows the instructor to collect various kinds of feedback. Polls may be used before or after class lessons. Polling before a lesson is used to probe background knowledge; it allows the instructor to gauge the learners' knowledge before the beginning of the lesson. This prevents the instructor from advancing to topics before students are ready. Polling after a lesson offers immediate feedback that helps identify ongoing learning issues; this helps the instructor identify areas that need further clarification before moving on to subsequent topics. For example, an open poll activity can be a question such as, "Any questions about the lecture?" Students respond to the question anonymously. Figure 1 shows a typical screen on the student side. If any student posts a question, it will also be displayed on all participants' screens. Anyone may add new items at any time, then use the "Empty" block to rank questions posted by all students. Figure 2 shows a sample result of the open poll. The result clearly showed that students were not quite understanding what is polymorphism and more clarification on this concept was needed before moving to the next subject. 


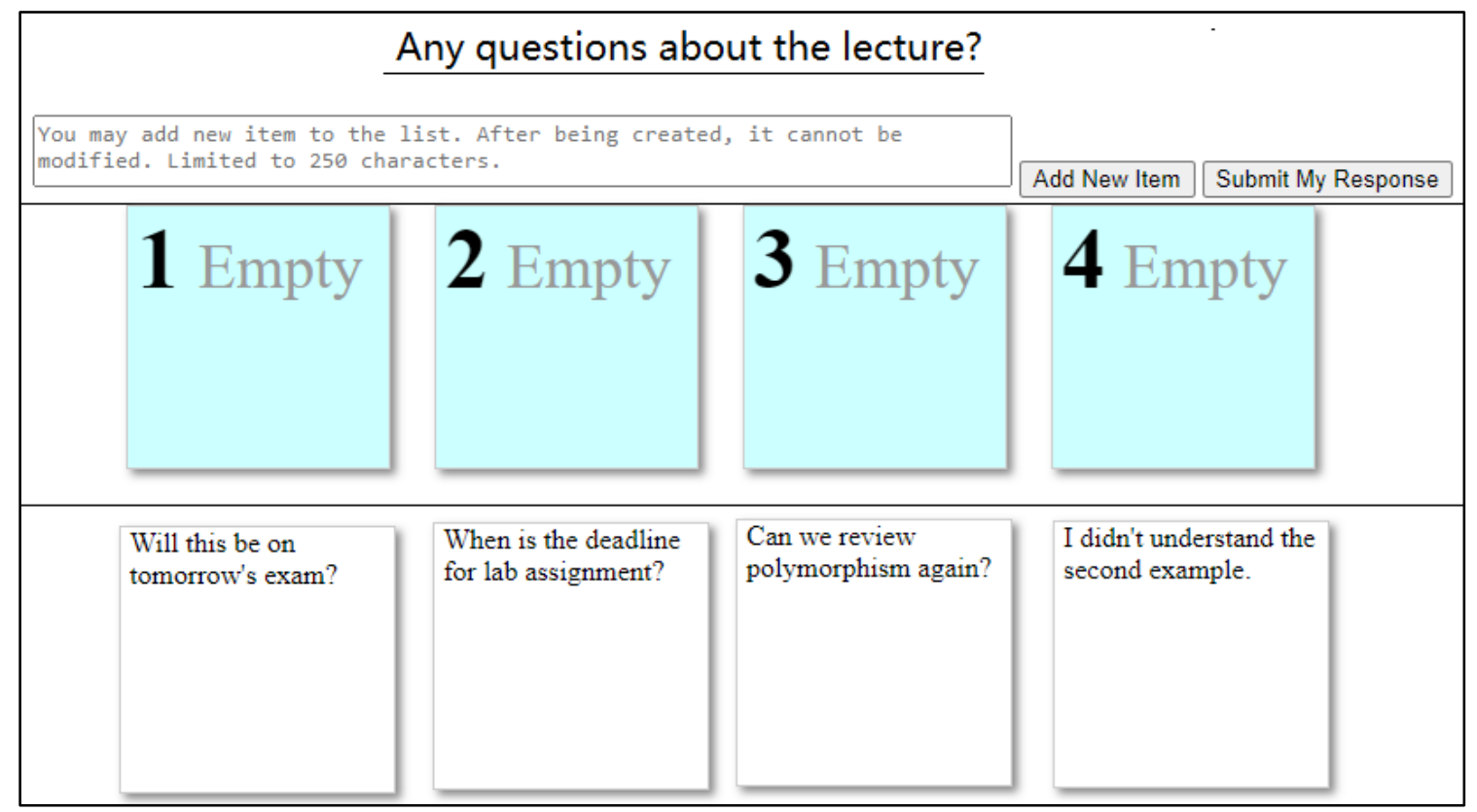

Figure 1: Sample Open Poll Screen On Student Side.

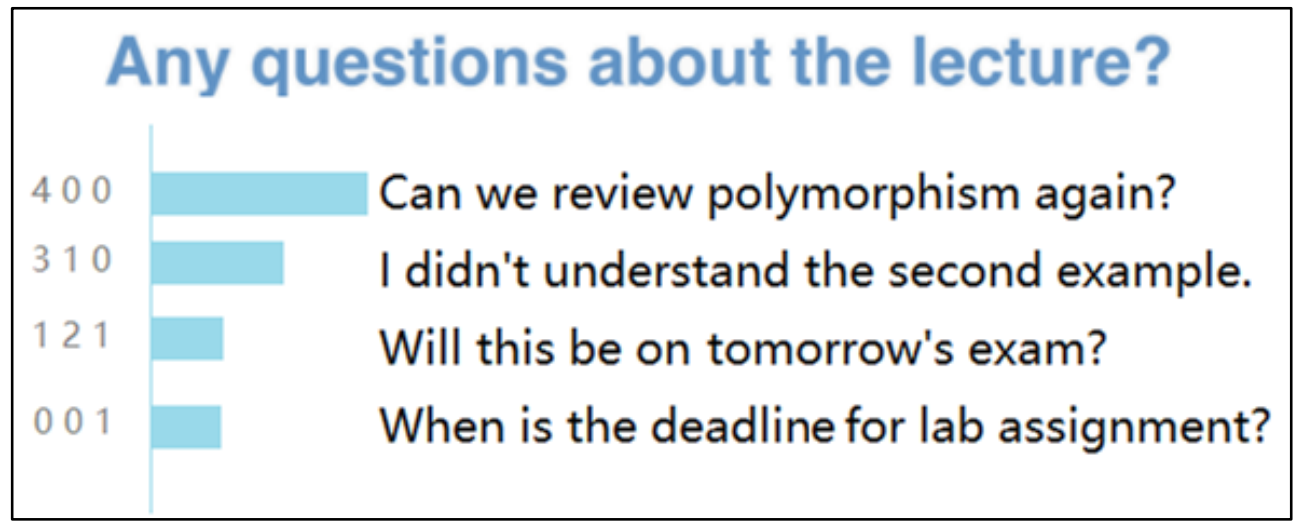

Figure 2: Sample Results of an Open Poll Activity

Communicating with students: Communicating through schedules, assignments, class activities, and progress status through a single interface.

All the activities (various types of assessments) embedded in course content should align with course outcomes. Activities/assessments should be designed in ways that will allow students to demonstrate mastery of course content. The activities should also foster students' engagement and motivate participation. In practice, instructors need to design tasks that reflect the level of understanding of the topics. Bloom's taxonomy (Figure 3) illustrates the types of assessments that are aligned with various cognitive levels of learning outcomes. 


\section{Issues in Information Systems}

Volume 22, Issue 4, pp. 83-92, 2021

BLOOM'S TAXONOMY

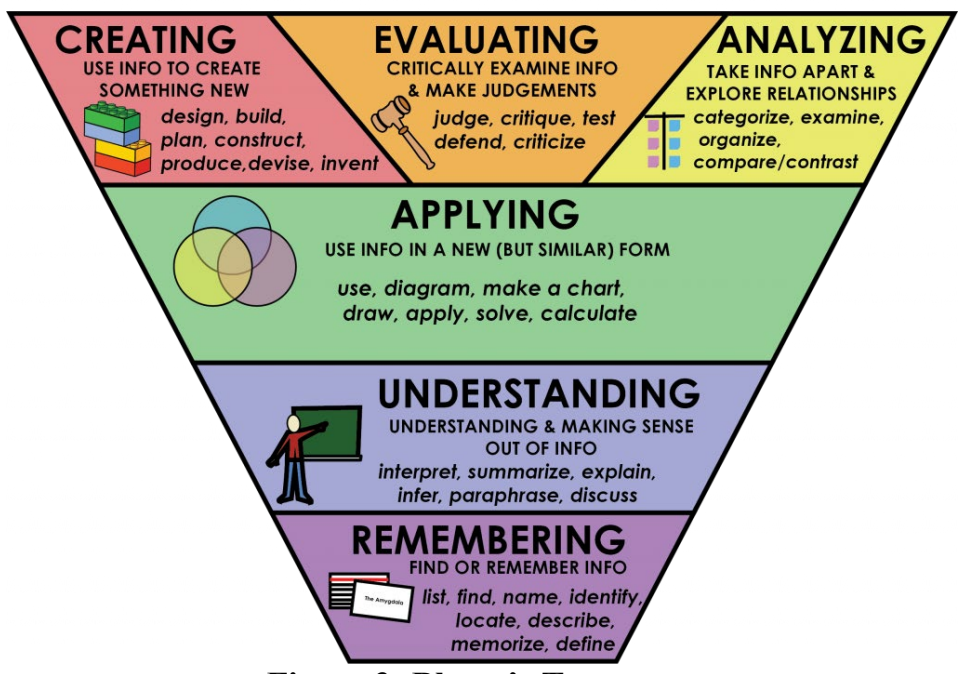

Figure 3: Bloom's Taxonomy

Source: https://www.thoughtco.com/blooms-taxonomy-the-incredible-teaching-tool-2081869

The following table lists some activities that can be easily implemented in any instructional setting.

Table 1: Engagement Strategies and Activities

\begin{tabular}{|c|c|}
\hline Strategies & Activities \\
\hline $\begin{array}{l}\text { Note taking } \\
\text { Guided/interactive note taking }\end{array}$ & $\begin{array}{l}\text { Provide template for each subject and make it available before class. } \\
\text { Require students to submit completed note with due date. }\end{array}$ \\
\hline Poll & $\begin{array}{l}\text { Frequent poll activities before, after, or in the middle of classes. Choose from a } \\
\text { variety of activity types that let you visualize responses in real time, like open- } \\
\text { ended Q \& As, multiple choice, and word clouds. Each activity type encourages } \\
\text { students' participation and provides various kinds of feedback. }\end{array}$ \\
\hline Frequent Assessment & $\begin{array}{l}\text { Quick quizzes, use of short journal entries, use of tournament tools that are } \\
\text { implemented in the LMS. Pop quizzes should be closely tied to the lecture. }\end{array}$ \\
\hline Establish a routine for students. & $\begin{array}{l}\text { Provide detailed schedules and communicate with students via announcements } \\
\text { and emails. Make use of a LMS that automatically propagates activities lists } \\
\text { with due dates and progress status (in-process, not started, or completed). }\end{array}$ \\
\hline $\begin{array}{l}\text { Build content that invites and } \\
\text { excites student participation. }\end{array}$ & $\begin{array}{l}\text { Research has shown that students prefer googling, YouTube, and other media } \\
\text { tools to learn. Integrate these tools and/or contents. }\end{array}$ \\
\hline $\begin{array}{l}\text { Provide ways for students to } \\
\text { track their progress. }\end{array}$ & $\begin{array}{l}\text { Timely feedback on assessments, tools to track missing assignments, progress } \\
\text { assessments, and students' efforts in the course, including time spent on reading, } \\
\text { coding, etc. Use a LMS that provides tracking capability. }\end{array}$ \\
\hline Active Collaborative Learning & $\begin{array}{l}\text { Group assignments, projects, small group debates, presentations, live } \\
\text { collaboration activities via collaboration tools, such as Google Doc, or } \\
\text { collaboration tools provided by the LMS. }\end{array}$ \\
\hline Clear course goals & Have clear course goals, schedules, expectations, deadlines, etc. \\
\hline Content format & Presentations with retainable content, note-taking, etc. \\
\hline Instructor feedback & $\begin{array}{l}\text { On time feedbacks, actionable information/guideline on how students can } \\
\text { improve, and adaptiveness to student needs. Use item analysis tool to } \\
\text { systematically identify students' needs as a group or individually. }\end{array}$ \\
\hline Active engagement & $\begin{array}{l}\text { Meaningful engagements, collaborative tasks, and credit for posts and } \\
\text { participation. }\end{array}$ \\
\hline
\end{tabular}




\section{Issues in Information Systems}

Volume 22, Issue 4, pp. 83-92, 2021

\section{A practical framework: three driving forces to engage students in the learning process}

Sustained engagement often depends on good instruction, easy-to-follow routine, and progress report (Shernoff, Csikszentmihalyi, Schneider \& Shernoff, 2014). Few students like watching someone lecture (face-to-face or synchronous online) nonstop for an hour. Chunk the lecture into shorter segments; find natural points to break up the content and engage students with the following activities: live survey with pre-prepared questions or open poll activity, kahoot or tournament on the topics just covered in class, pose questions that require students to collaborate their contributions to the questions with google doc, GroupMe, or collaborate editing tools embedded in the LMS, for programming classes, transfer demo coding to the individual student. Based on our teaching experiences and literature on students' engagement, we identified three driving forces that foster students' engagement in the learning process. The three driving forces include, content design, technology or tools to seamlessly deliver content and monitor progress of activities. The framework is illustrated in Figure 4.

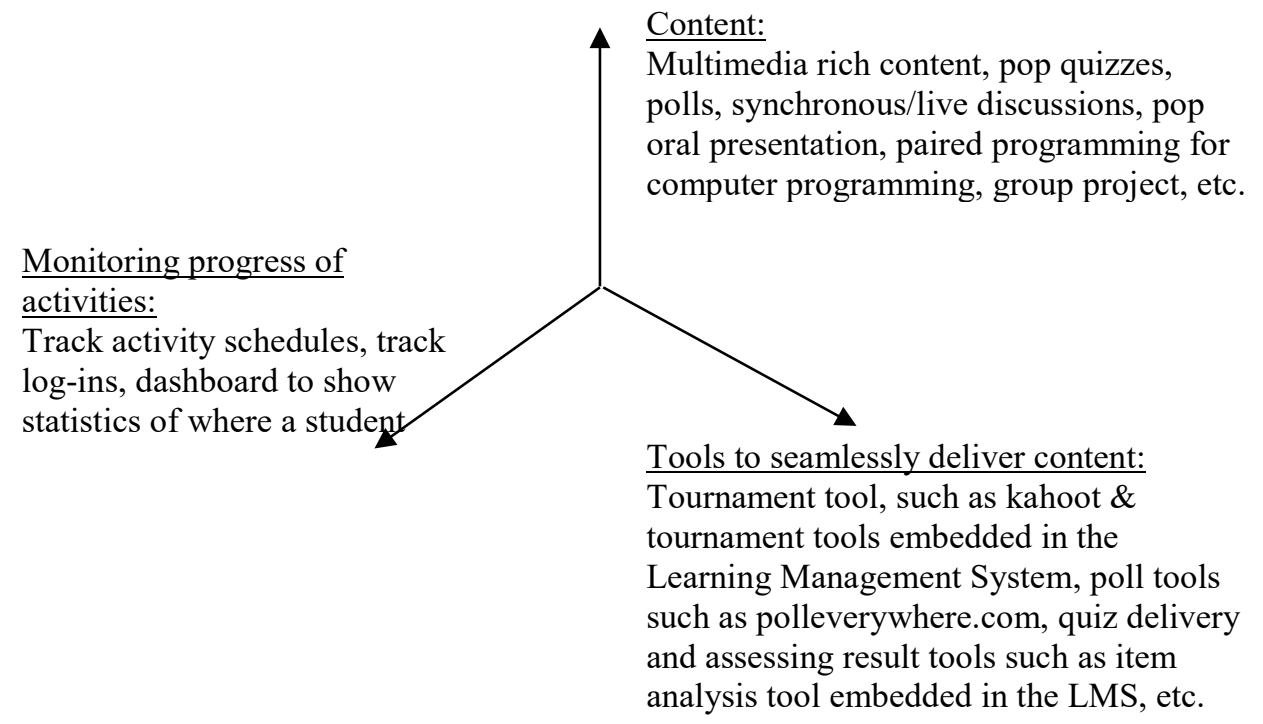

Figure 4: Three Driving Forces to Foster Student Engagement in the Learning Process

It will be challenging to implement the framework in real instructional settings without tools or technology support. An LMS platform using Learning Implements provides integrated tools for all activities listed in the framework. In the next phase, the control group methodology will be used to evaluate effectiveness of the framework in improving students' engagement in the learning process. The following list provides guidance, tips, and strategies that may be used to foster student engagement in actual instructional settings:

1. Make logging into class a regular necessity: if there is a regular expectation of practice built into the course, students will get in the habit of logging in. To encourage students to login on a regular basis, provide statistics on logging in for the entire class to be displayed on dashboard.

2. Identify students who do not login regularly and communicate with them in a timely manner.

3. Make frequent use of poll tools: polling before a lesson is used to probe background knowledge; it allows the instructor to gauge the students' knowledge before the beginning of the lesson and prevents students from advancing to topics before they are ready. It offers immediate feedback that helps identify ongoing learning issues. This ensures that students aren't left behind. 


\section{Issues in Information Systems}

Volume 22, Issue 4, pp. 83-92, 2021

4. Make frequent use of tools to engage students in class activities: quizzes, poll, survey, etc. The tools provide mechanisms for engaging students in the classroom and helps identify learning issues.

5. Establish routines for class activities: provide standardized activities lists for each class, schedules for those activities, and display all tasks with appropriate flags to indicate past due, inprocess, and completed activities.

\section{Summary}

Student engagement and student interest during class instruction are important conditions for active learning. Few students like watching someone lecture (face-to-face or synchronous online) nonstop for an hour. Chunk the lecture into shorter segments; find natural points to break up the content and engage students with the following activities: live survey with pre-prepared questions or open poll activity, kahoot or tournament on the topics just covered in class, pose questions that require students to collaborate their contributions to the questions with google doc, GroupMe, or collaborate editing tools embedded in the LMS, for programming classes and transfer demo coding to individual student. In order to achieve the desired learning outcomes, it is critical to provide a compelling presentation and well-designed activities that engage everyone while conveying information seamlessly and effectively. In this paper, we have proposed a practical framework for fostering student engagement that can be easily implemented through a LMS. The framework consists of three driving forces including content design, tools to deliver contents and activities, and monitoring progress of activities. We believe students' engagement should be significantly improved if the framework is implemented well in an instructional setting.

\section{References}

Al-Zahrani, A. M. (2015). From passive to active: The impact of the flipped classroom through social learning platforms on higher education students' creative thinking. British Journal of Educational Technology,46 (6), 1133-1148.

Bai, X., Ola, A. Eyob, E., Reese, S., Akkaladevi, S., \& Downing, D. (2019) “Another Look at Textbook Usage by College Students”. Issues in Information Systems, Volume 20, Issue 4, pp. 35-44, 2019.

Busse, V. (2013). Why do first-year students of German lose motivation during their first year at university? Studies in Higher Education 38(7), 951-971. http://dx.doi.org/10.1080/03075079.2011.602667.

Deci, E., \& Ryan, R. (2002). Handbook of self-determination research. Rochester, NY: The University of Rochester Press.

DiMenichi, B. \& Tricomi, E. (2015). The power of competition: Effects of social motivation on attention, sustained physical effort, and learning. Retrieved on June 5, 2021 from: https://doi.org/10.3389/fpsyg.2015.01282.

Esposto, A.S. \& Weaver, D. (2011). Continuous Team Assessment to Improve Student Engagement and Active Learning. J. Univ. Teach. Learn. Pract. 2011, 8, 8.

Groves, M., Sellars, C., Smith, J. \& Barber, A. (2015). Factors Affecting Student Engagement: A Case Study Examining Two Cohorts of Students Attending a Post-1992 University in the United Kingdom. International Journal of Higher Education. 4. 10.5430/ijhe.v4n2p27. 


\section{Issues in Information Systems}

Volume 22, Issue 4, pp. 83-92, 2021

Gunuc, S. (2014). The Relationships Between Student Engagement And Their Academic Achievement. International Journal on New Trends in Education and Their Implications. October 2014 Volume: 5 Issue: 4 Article: 19 ISSN 1309-6249.

Holmes, N. (2018). "Engaging with assessment: Increasing student engagement through continuous assessment," Active Learning in Higher Education, vol. 19, no. 1, pp. 23-34, 2018.

Kahn, P., Everington, L., Kelm, K., Reid, I. \& Watkins, F. (2017). Understanding student engagement in online learning environments: The role of reflexivity. Educ. Technol. Res. Dev. 2017, 65, 203218.

Kuh, G. D., Cruce, T. M., Shoup, R. \& Kinzie, J. (2008). "Unmasking the effects of student engagement on first-year college grades and persistence," The Journal of Higher Education, vol. 79, no. 5, pp. 540-563, September/October 2008. Doi: 10.1353/jhe.0.0019.

Kuh, G., Kinzie, J., Buckley, J., Bridges, B. \& Hayek, J. (2006). What matters to student success: A review of the literature. Retrieved on March 6, 2009, from https://nces.ed.gov/npec/pdf/kuh team report.pdf.

Lizzio, A., Wilson, K., \& Simons, R. (2002). University Students' Perceptions of the Learning Environment and Academic Outcomes: Implications for Theory and Practice. Studies in Higher Education, 27(1), 27-52.

Llorens, S., W. Schaufeli, A. Bakker \& Salanova, M. (2007). Does a positive gain spiral of resources, efficacy beliefs and engagement exist? Computers in Human Behaviour 23, 825-41. http://dx.doi.org/10.1016/j.chb.2004.11.012.

McCormick A.C., Kinzie J., Gonyea R.M. (2013) Student Engagement: Bridging Research and Practice to Improve the Quality of Undergraduate Education. In: Paulsen M. (eds) Higher Education: Handbook of Theory and Research. Higher Education: Handbook of Theory and Research, vol 28. Springer, Dordrecht. https://doi.org/10.1007/978-94-007-5836-0_2.

Moran, E. \& Gonyea, T. (2003). The influence of academically-focused peer interaction on college students' development. ERIC Document Reproduction Service No. ED478773.

Mushtaq, I. \& Khan, S. N. (2012). Factors Affecting Students' Academic Performance. Global Journal of Management And Business Research, [S.1.], v. 12, n. 9, june 2012. ISSN 2249-4588. Available at: https://www.journalofbusiness.org/index.php/GJMBR/article/view/721. Date accessed: 04 June 2021.

Nepal, R. \& Rogerson, A. M. (2020). From Theory to Practice of Promoting Student Engagement in Business and Law-Related Disciplines: The Case of Undergraduate Economics Education. Education Sciences. 2020, 10, 205; doi:10.3390/educsci10080205.

Radovan, M., (2019). "Should I stay, or should I go? Revisiting student retention models in distance education,” Turkish Online Journal of Distance Education, vol. 20, no. 3, pp. 29-40, July 2019. 


\section{Issues in Information Systems}

Volume 22, Issue 4, pp. 83-92, 2021

Romer, D. (2020). Do students go to class? Should they? J. Econ. Perspect. 1993, 7, 167-174. Education Sciences, 2020, 10, 20510 of 13.

Russell, B. \& Slater, G. (2011). Factors that encourage student engagement: Insights from a case study of 'first time' students in a New Zealand University. Journal of University Teaching and Learning Practice 8(1) article 7.

Shernoff, D.J., Csikszentmihalyi, M., Schneider, B. \& Shernoff, E.S. (2014) Student Engagement in High School Classrooms from the Perspective of Flow Theory. In: Applications of Flow in Human Development and Education. Springer, Dordrecht. https://doi.org/10.1007/978-94-017-90949_24.

Stanca, L. (2006). The effects of attendance on academic performance: Panel data evidence for Introductory microeconomics. J. Econ. Educ. 2006, 37, 251-266.

Tsinidou, M., Gerogiannis, V. \& Fitsilis, P. (2010). Evaluation of the factors that determine quality in higher education: an empirical study. Quality Assurance in Education, 18(3), 227-244.

Zepke, N., Butler, P. \& Leach, L. (2012). Institutional research and improving the quality of student engagement. Quality in Higher Education 18(3), 329-47. http://dx.doi.org/10.1080/13538322.2012.730338.

Zepke, N., Leach, L. \& Butler, P. (2010). Student engagement: What is it and what influences it? Wellington, Teaching and Learning Research Initiative. http://www.tlri.org.nz/sites/default/files/projects/9261-Introduction.pdf.

Umbach, P. \& Wawrzynski, M. (2005). Faculty do matter: The role of college faculty in student learning and engagement. Research in Higher Education 46(2), 153-84. http://dx.doi.org/10.1007/s11162004-1598-1.

Yorke, M. \& Knight, P. (2004). Self-theories: Some implications for teaching and learning in higher education. Studies in Higher Education 29(1), 25-37. http://dx.doi.org/10.1080/1234567032000164859. 